\title{
Ceticismo e fé na dissertação sobre o pirronismo de Michel de Montaigne
}

Guilherme Grané Diniz

\section{Resumo}

Entre os vários ensaios de Michel de Montaigne, o mais "estritamente" filosófico é a Apologia de Raymond Sebond. Nesse, Montaigne apresenta uma de suas principais contribuições à filosofia: uma reformulação do pensamento pirrônico. O cerne dessa reformulação se encontra em um trecho específico do ensaio, o qual se convencionou chamar "dissertação sobre o pirronismo". Neste artigo, buscaremos analisar a argumentação e as fontes que compõem o texto de Montaigne de modo a nos permitir melhor compreender as peculiaridades de sua leitura da doutrina pirrônica, especialmente diante das formulações mais "canônicas" que foram suas fontes. Pretendemos, desse modo, ressaltar como uma das marcantes e relevantes especificidades dessa leitura é a relação que Montaigne traça entre um projeto filosófico e um religioso - vale dizer, entre ceticismo e fé.

Palavras-chave: Montaigne - Pirronismo - Cristianismo - Fé. 
No ano de I487, Raymond Sebond publicava seu Liber naturae sive creaturarum etc., obra na qual buscava demonstrar por meio da razão e das evidências naturais encontradas no mundo os artigos da fé cristã (MONTAIGNE, 2006). Desde a publicação, esse livro fora consideravelmente popular, e ainda à época de $\mathrm{Mi}$ chel de Montaigne - quase duzentos anos depois - gozava de boa fortuna. Sua simplicidade e um tom deveras piedoso fizeram dele um dos favoritos entre as mulheres letradas da época. A rainha Margarida de Valois, a quem se acredita ter sido dedicado o ensaio sobre o qual comentaremos (MONTAIGNE, 2006), era uma mulher de considerável erudição, e parece ter se utilizado dessa obra como fonte de apologética cristã diante dos reformistas da fé católica que encontrou na corte de Navarra (MAIA NETO, 2OI2). Pelo que consta, foi ela, juntamente a outras senhoras da corte, que solicitou a Montaigne que escrevesse sobre a obra de Sebond, cujas teses estavam sob ataque por parte de teólogos calvinistas instalados na corte espanhola, os quais invocavam a doutrina acadêmica para defender a verossimilhança de suas proposições (MAIA NETO, 20I2).

A relação de Montaigne com o Livro das Criaturas, no entanto, precede esse pedido. Remonta ao episódio no qual seu pai o recebera como presente do humanista Pierre Bunel, "homem com grande reputação de sabedoria em seu tempo", com a recomendação de ser este um "livro muito útil e adequado para a época em que lho deu" (entenda-se, a época do nascimento e da difusão das diversas religiões protestantes) (MONTAIGNE, 2006, p. 6I). Ainda em vida, o senhor de Montaigne pediu a seu filho que traduzisse o livro, já que pouco conhecia do latim. A tradução foi publicada pouco após sua morte. Indícios apontam certo grau de investimento afetivo na relação entre Montaigne e a obra de Sebond, dada essa história.

Desde criança Montaigne fora educado, a mando de seu pai, por preceptores de religiões diferentes, em um ambiente intelectual no qual a tolerância religiosa era um valor preponderante: isso influencia muito fortemente seu pensamento pirrônico e sua leitura do livro de Sebond (POPKIN, 2003). Deste modo, mesmo sem à época já ter publicado seus Ensaios, parece razoável pensar que possivelmente Montaigne era então uma das pessoas mais bem indicadas para proceder a tal apologia. Com fito de atender a esse pedido, o autor juntou diversos trechos que havia escrito ao longo dos anos de I576 a I578 (MONTAIGNE, 2006), acrescentou novas considerações e com isto formou o ensaio que é considerado o mais ortodoxamente filosófico e também o mais complexo, bem como o mais extenso, de sua obra: a Apologia de Raymond Sebond.

Dentro desta, responde ele a duas principais objeções feitas ao autor. A primeira, de natureza fideísta e piedosa, diz que "os cristãos estão errados em querer apoiar com razões sua crença, que só se concebe por fé e uma inspi- 
ração divina" (MONTAIGNE, 2006, p. I63), como buscou fazer Sebond. Montaigne concorda com isto, apesar de ainda assim salvaguardar o autor. Alguns dos temas levantados na resposta a esta objeção são relevantes como chave para a compreensão da posição geral de Montaigne sobre Sebond, de modo que serão oportunamente retomados. A segunda objeção concerne o mérito das afirmações do teólogo. De acordo com esta, seus argumentos são "fracos e inadequados para demonstrar o que ele pretende" (MONTAIGNE, 2006, p. I75). Em relação a tal objeção, Montaigne procede a uma defesa pouco ortodoxa, e que muitos autores chamaram posteriormente de contraditória ou paradoxal. Em vez de mostrar a qualidade dos argumentos do pensador catalão por meio de considerações teológicas (o que seria um caminho mais esperado), ele procede a explicar como nenhum argumento humano, seja de Sebond ou dos doutores que o criticam, tem qualquer qualidade ou capacidade de atingir a verdade. O único valor que o pensamento de Sebond tem é devido à inspiração e piedade com o qual foi escrito; valor que os escritos polêmicos dos calvinistas não possuem.

É no seio da resposta a esta objeção, inserida em meio a uma série de variadas considerações sobre a incapacidade do homem de encontrar a verdade, que se localiza a dissertação sobre o pirronismo, a qual, de acordo com Pierre Villey (apud MONTAIGNE, I987, p. 35), é o núcleo desse ensaio. Aqui Montaigne expõe detalhada e sistematicamente sua concepção sobre a doutrina que encontrou nas leituras de Sexto Empírico e Diógenes Laêrtios. Por meio desta, podemos compreender a aquisição peculiar do pirronismo pelo autor francês e notar seus pontos de contato e de afastamento em relação à versão que podemos dizer mais canônica da doutrina, consubstanciada principalmente nas Hipotiposes pirrônicas de Sexto Empírico (2007). Por sinal, este autor da antiguidade helênica, já no início da obra aqui referida, afirma que o ceticismo passa por dois tipos de argumentação: uma geral e outra específica. Quanto à geral, diz ele ser a exposição das

[...] características próprias do ceticismo, seus propósitos e princípios, seus argumentos, seu critério e seus objetivos, assim como os "tropos" ou "modos" que levam à suspensão do juízo, o sentido em que adotamos as fórmulas céticas, bem como a distinção entre o ceticismo e as filosofias com que se relaciona (SEXTO EMPÍRICO, 2007, p. 9).

Ficará bastante claro ao longo de nossa exposição como de algum modo Montaigne procedeu na dissertação sobre o pirronismo a uma argumentação geral de sua versão da doutrina. 
Montaigne, ao compor seus ensaios, tinha uma evidente preocupação de tipo "estético" ou "arquitetônico". Tome-se como exemplo outro de seus mais belos e interessantes ensaios: Da amizade. O ensaio é localizado no meio do primeiro livro dos Ensaios. Ainda, é exatamente no centro desse que deveria se encontrar o Discurso da servidão voluntária, de Étienne de la Boétie. Montaigne tinha o interesse de produzir com isso um efeito de tipo artístico, como quando se coloca uma pintura bela em meio a outras bizarras e fantasiosas, com o fim de, pelo contraste, ressaltá-la (TOURNON, 2004). No que diz respeito ao texto que estamos observando, podemos perceber que essa dissertação se encontra dentro do ensaio como que em uma moldura.

Antes de adentrar na argumentação propriamente pirrônica, Montaigne nos faz lembrar que todo o conhecimento da verdade que temos não foi por nossos meios adquirido, mas "Deus ensinou-nos plenamente isso pelas testemunhas". E essas testemunhas não foram escolhidas aleatoriamente, Deus as "escolheu em meio ao vulgo, simples e ignorantes". A fé, que é modo privilegiado de acesso profundo ao conhecimento da verdade, não se acessa pelo saber, pelo contrário, "a fragilidade de nosso julgamento nos auxilia mais nisso que a força, e nossa cegueira mais que nossa clarividência" (MONTAIGNE, 2006, p. 250-25I). A conclusão que Montaigne extrairá da argumentação pirrônica retoma este ponto de partida: a utilidade da doutrina de Pirro de Élis é livrar nossa mente dos pretensos conhecimentos que possuímos para abrir espaço para a revelação divina:

[...] ela apresenta o homem nu e vazio, reconhecendo sua fraqueza natural, apropriado para receber do alto uma força externa, desguarnecido de ciência humana e portanto mais apto para alojar em si a divina, anulando seu próprio julgamento a fim de dar mais espaço para a fé (MONTAIGNE, 2006, p. 260).

Tudo isso, claro, de forma a favorecer a aceitação piedosa da doutrina inspirada e iluminada de Sebond contra os argumentos protestantes:

[...] [o cético é] inimigo jurado da heresia e consequentemente isentando-se das ideias irreligiosas e vãs introduzidas pelas falsas seitas. É uma tábula rasa preparada para assumir pelo dedo de Deus as formas que este aprouver nela gravar (MONTAIGNE, 2006, p. 260).

É relevante termos em mente esta moldura, pois o tema que guiará as particularidades na interpretação de Montaigne sobre o pirronismo é (entre outras coisas, certamente) a relação entre ceticismo e fé. Autores relevantes, como 
Richard Popkin (2003), tomam essa relação como tão importante a ponto de compreender que - bem como fizeram antes de Popkin alguns apologistas do cristianismo do século que o precedeu (e.g. o profeta Savonarola, Gianfrancesco Pico della Mirandola, Agrippa von Nettesheim) - Montaigne se utilizou do pirronismo como ferramenta para dar suporte a uma doutrina fideísta.

$\mathrm{O}$ argumento de Montaigne começa com uma exposição muito cara ao pirronismo em geral, a da "diafonia", pela qual se entende a multiplicidade de opiniões que os homens sustentam e que leva a "um contraste intensíssimo e uma grande confusão" (LAÊRTIOS, 20I4, p. 275) - trata-se do primeiro modo cético de Agrippa. Os séculos de atividade filosófica que se acumularam serviram para mostrar-nos apenas como os homens em tudo discordavam. Ao invés de nos revelarem verdades, só fizeram ver com clareza nossa ignorância. Os grandes sábios da antiguidade também notaram isto: à medida que envelheciam, abdicavam de suas certezas e reconheciam a fraqueza nos argumentos que por toda a vida defenderam. Ainda neste argumento de autoridade, Montaigne invoca as famosas palavras do homem que, de acordo com ele, é o mais sábio que existiu: "quando lhe perguntaram o que sabia, respondeu que sabia que nada sabia" (MONTAIGNE, 2006, p. 252). Outro exemplo muito caro a Montaigne é o de Cícero, que

[...] na velhice começou a desestimar as letras. E enquanto as cultivava era sem compromisso com facção alguma, seguindo o que lhe parecia provável, ora numa seita, ora noutra, submetendo-se sempre à dúvida da Academia (MONTAIGNE, 2006, p. 253).

A respeito do uso insistente de Cícero por parte de Montaigne, algumas palavras devem ser ditas. Entre as citações, marcas distintivas na escrita deste autor, percebemos neste trecho que existem seis citações diretas extraídas de obras de Cícero, duas de Lucrécio, e uma da Bíblia, excluídas as muitas paráfrases e referências. É notável como um autor cristão e pirrônico prefere buscar suas fontes em um autor pagão e acadêmico a fazê-lo nos autores pirrônicos (a despeito das paráfrases de Sexto Empírico) ou mesmo na própria Bíblia. A respeito das citações em geral, Montaigne nos lembra que quando fala sobre os outros, entenda-se, os autores antigos, é para falar de si mesmo (TOURNON, 2004). Hugo Friedrich (I99I) nos explica que Montaigne seleciona os objetos que cita de tal modo que os contamina, distorcendo e descontextualizando os trechos incorporados para que ao fim eles reflitam somente seu próprio caráter. Deste modo, seria justificado o uso de um autor acadêmico para a defesa da doutrina de Pirro, dado que, mesmo nas citações de Cícero, 
é a voz de Montaigne que nos fala. Mas, ainda assim, cumpre notar que um dos pontos de distanciamento entre Montaigne e Sexto Empírico é que aquele atribui maior valor ao academicismo que ao propriamente dogmático - o que justificaria seu uso dentro de um contexto cético pirrônico -, enquanto este não parece fazer tal distinção.

A crítica à facciosidade das escolas dogmáticas de pensamento, que vemos na passagem de Cícero citada anteriormente, permite também revelar algo sobre o verdadeiro alvo da argumentação de Montaigne: não o povo, mas sim o homem "em sua mais alta condição". O homem médio "deixa ociosa a maior parte de suas faculdades naturais" (MONTAIGNE, 2006, p. 253), quer dizer, sua reflexão não tem o mesmo grau de complexidade e refinamento que aquelas das escolas que Cícero abandonou. Vale notar que estes homens dogmáticos, descritos como "excelentes", "dotados de uma bela e particular força natural", parecem ser na verdade os filósofos antigos e aqueles que ecoam suas doutrinas. Isto é perceptível quando vemos a descrição que Montaigne nos dá dos grandes sábios da antiguidade; "almas raras e excelentes", "abundantemente munidas de forças naturais" (MONTAIGNE, 2006, p. I64). Griticar estes homens que atingiram o ponto mais alto da sabedoria permite a Montaigne criticar, por tabela, todos os que forem menos sábios (MONTAIGNE, 2006, p. 254), seja seus contemporâneos - especialmente aqueles doutores teólogos que pretendem atingir o conhecimento de Deus a partir do pensamento e da razão -, seja o homem comum, que sequer se questiona sobre o dogmatismo "que julga a verdade não pelo peso das vozes mas pelo número" (MONTAIGNE, 2006, p. 253).

Ao verificar as conquistas desses homens muito sábios, o autor procede a uma paráfrase quase literal de parte do primeiro capítulo do primeiro livro das Hipotiposes pirrônicas (SEXTO EMPÍRICO, 2007). Ele nos explica os três tipos de filosofia - dogmática, acadêmica e pirrônica - por meio dos possíveis resultados de uma investigação: a certeza de ter encontrado um resultado, a certeza de que não se pode encontrar um resultado e a incerteza, de modo que se continua a busca. Neste ponto nos é permitido entrever a já referida hierarquia estabelecida entre acadêmicos e dogmáticos, quando o autor nos diz que aquele partido teve "o maior número de adeptos e os seguidores mais nobres" e também que, enquanto os dogmáticos "enganam-se infinitamente", entre os acadêmicos apenas existe "vaidade ousada" (MONTAIGNE, 2006, p. 254).

Também por aqui podemos saber que, além de Sexto Empírico, outra relevante fonte do ceticismo para Montaigne foi Diógenes Laêrtios. Isto vemos ao notar que, quando enumera os filósofos de cada escola, para os acadêmicos e os dogmáticos usa os mesmos exemplos de Sexto, mas, como para os pirrô- 
nicos ele não fornecera exemplos, Montaigne recorre exatamente aos mesmos dados por Diógenes (LAÊRTIOS, 20I4).

Os acadêmicos não são céticos o suficiente pois não foram capazes de ignorar sua própria ignorância, o que é facultado ao pirrônico. Isto nos remete ao ponto no qual Montaigne trata sobre os modos de falar do ceticismo. Isso é muito relevante, pois, segundo alguns autores, a questão central posta pelo ceticismo é algum tipo de análise da linguagem e dos modos de utilizá-la sem dogmatizar (PORCHAT, 2OI6). Montaigne distingue entre três ações da alma: imaginativa, apetitiva e assentidora, sendo que a esta última cabe fazer juízos a respeito das coisas e é dela que o pirrônico não faz uso. Montaigne utiliza-se de um exemplo de Zenão para explicar figuradamente estas ações:

[...] a mão estendida e aberta era a aparência; a mão meio fechada e com os dedos um pouco curvados, o consentimento; o punho fechado, compreensão; e quando a mão esquerda vinha fechar ainda mais estreitamente este punho, a ciência (MONTAIGNE, 2006, p. 255).

Ora, o que se depreende é que a ciência seria um grau de certeza por demais elevado e difícil de se obter. Esta atitude de não aderir (como uma mão adere à outra) às coisas leva o cético à $\alpha \tau \alpha \varrho \alpha \xi i ́ \alpha$ (ataraxia), uma situação de calma e imperturbabilidade.

É notável que a situação contrária, a do homem que acredita ter ciência das coisas, leva a uma série de vícios, isto apesar de Montaigne ter dito ser a ciência uma coisa bastante útil (MONTAIGNE, 2006). Ele elenca uma série de vícios que a ciência desperta, dentre os quais alguns merecem ser notados. Entre outros, a ciência causa: o orgulho, o qual, segundo uma tradição cristã agostiniana, é entendido como o pecado original e o pior dentre todos, sendo este que impede a salvação do homem; o amor à novidade, entenda-se, a aceitação das inovações em termos de religião, que desafiam a tradicional Igreja Católica e sua autoridade (note-se que é justamente contra estas novidades e seus adeptos que Montaigne está escrevendo), enfim, também é disto que surge a maioria dos males corporais. Veremos que esta questão do corpo surge novamente e de forma muito relevante ainda dentro do trecho sob comento, e já foi tratada antes na resposta à primeira objeção. Lá, Montaigne nos explica que "não nos contentamos em servir a Deus com o espírito e com a alma; devemos-lhe ainda, e lhe prestamos, uma reverência corporal; aplicamos em honrá-lo nossos próprios membros e nossos movimentos e as coisas externas" (MONTAIGNE, 2006, p. I64). Vale dizer, os homens percebem a necessidade de se prostrar de joelhos e juntar as mãos para orar, de comer determi- 
nado alimento após uma série de gestos específicos etc., gestos que, por si, não têm muito sentido, mas os quais a fé torna significativos.

Essa afirmação faz parte da defesa da posição católica de Sebond. Os protestantes eram justamente aqueles que negavam a validade ou a necessidade de tais atos, considerando-os ilógicos, irracionais ou mesmo ofensivos. Discordâncias sobre este tema eram um ponto de tensão intelectual entre católicos e protestantes. Quanto à questão dos males corporais, tanto Sexto quanto Diógenes dela tratam. O homem comum, dogmático, sofre pela dor que sente e sofre ainda mais por acreditar ser ela um mal (SEXTO EMPÍRICO, 2007, p. I2I). Na verdade, esta crença responde pela maior parte do sofrer. Sexto, que foi médico, conta a anedota de que enquanto opera um paciente, este aguenta bravamente a tortura do corte, enquanto aquele que fica a seu lado, sem sentir a dor, mas apenas pela imaginação de quão horrível deve ser - imaginação que deriva de sua crença em ser a dor um mal em si -, fica pálido e logo desmaia (SMITH, I996). Também o próprio Pirro, de acordo com Diógenes, passava por cirurgias sem alterar-se (LAÊRTIOS, 20I4, p. 269). Parece muito razoável sustentar acerca de Montaigne algo semelhante ao que Porchat (2016) sustenta de Sexto Empírico: o cético é apenas um homem comum, fazendo uso de suas faculdades naturais do jeito que melhor lhe parece.

Mostrando que as aflições corporais são, em sua principal parte, males morais, é importante considerar que o cético pirrônico se livra principalmente destes: o ceticismo serve como que uma terapia contra o dogmatismo (PORGHAT, 20I6). Isso significa, então, que não apenas o cético não se aflige pela dor, mas também não o faz pelas disputas entre doutrinas. Isto pois, em uma discussão, basta para o cético que se prove que alguém estava errado, não sendo necessário que ele a ganhe (MONTAIGNE, 2006, p. 255), até porque ganhar ser-lhe-ia impossível: ele não sustenta opinião alguma e duvida inclusive da dúvida que professa (MONTAIGNE, 2006, p. 256). Para provocar a dúvida na discussão, Montaigne utiliza-se do que Sexto Empírico chama "dinamis antitética", a capacidade de opor coisas e pensamentos de todas as formas possíveis, aumentando a intensidade de suas dúvidas e tornando-as reflexivas - dúvidas sobre as dúvidas -, de modo a atingir a equipolência, situação na qual todos os argumentos são de igual peso e valor e sobre eles não decidimos (SEXTO EMPÍRICO, 2007). O exemplo trazido por Montaigne, dado seu caráter quase cômico e muito explicativo, merece ser lido do modo que está posto no texto:

Se declarardes que a neve é preta, argumentarão, ao contrário, que é branca. Se disserdes que não é uma coisa nem outra, cabe-lhes defender que é ambas. Se, 
com julgamento seguro, afirmardes que nada sabeis disso, eles vos sustentarão que sabeis. E mesmo se, por um axioma afirmativo, assegurardes que duvidais disso, eles irão debatendo convosco que não duvidais, ou que não podeis julgar e estabelecer que duvidais. E, por essa dúvida extrema que abala a si mesma, eles se afastam e se apartam de várias opiniões, inclusive das que defenderam de várias formas a dúvida e a ignorância (MONTAIGNE, 2006, p. 256).

Uma objeção que o dogmatismo parece interpor aos céticos é que eles devem sustentar alguma opinião, qualquer que seja esta, mesmo se a opinião for somente dúvida (MONTAIGNE, 2006). Montaigne nota que o dogmático, se aceita a doutrina de Platão, duvida da de Aristóteles, e se acredita que algo é amarelo, duvida que seja verde; se o dogmático pode duvidar de um partido, por que não poderiam os céticos duvidarem de todos? Afinal, Panécio duvidou inclusive de preceitos da própria escola. Ainda mais, aqueles que dão assentimento a algo muitas vezes o fazem por costume ou acaso, sem terem de fato escolhido (MONTAIGNE, 2006). Montaigne aqui está criticando aqueles que esposam uma ideia religiosa de modo dogmático e criticam a todas as outras, uma vez que as pessoas na verdade têm uma religião do mesmo modo que têm uma pátria, apenas por terem assim sido educadas e acostumadas. A crítica que Montaigne já na resposta à primeira objeção havia feito a respeito da religião, aqui ele estende a todo o conhecimento (MONTAIGNE, 2006), uma vez que esta objeção, diversamente da primeira, é feita no nível da razão e não da fé.

É fato, no entanto, que os céticos falam, afirmam, e mesmo sua escola ou doutrina tem suas máximas. Montaigne passa, então, a investigar as fórmulas céticas e modos de dizer do pirronismo, agora para mostrar como não é por meio dessas que se pode dizer do pirronismo ser dogmático. Nota ele que estas fórmulas servem para obter uma "pura, integral e completa interrupção e suspensão do julgamento" (MONTAIGNE, 2006, p. 258). Isto porque elas são enunciadas de modo a anularem a si mesmas, já que se aplicam a si. Por exemplo, quando o cético diz que "nada parece verdadeiro que não possa parecer falso", ele se refere inclusive à própria afirmação, tendo por consequência que ela não é usada de modo dogmático. Ainda, sua "palavra sacramental” é $\varepsilon \pi \varepsilon \chi \omega$, eu suspendo. Esta é uma conjugação do grego $\varepsilon \pi 0 \chi \varepsilon$, pela qual se entende o estado de incapacidade de dar assentimento a uma ou outra doutrina (BOLZANI, 20I3), a qual antecede a $\alpha \tau \alpha \varrho \alpha \xi i ́ \alpha$ (SEXTO EMPÍRICO, 2007). Quanto ao uso da razão, Montaigne faz um esclarecimento: o cético dela se utiliza para "inquirir e debater, mas não para decidir e escolher" (MONTAIGNE, 2006, p. 258). Isto nos remete à passagem na qual 
Sexto se indaga se o cético estuda as ciências naturais e conclui que, mesmo a resposta sendo sim, ele só o faz para debater, nunca para afirmar (SEXTO EMPÍRICO, 2007).

Pudemos ver antes como o pensamento cético articula a reflexão sobre a linguagem com aquela acerca da ação e da moral. É certo que, enquanto filosofia moral, o ceticismo também diz algo sobre o bem-viver. Montaigne mostrará que no aspecto moral do pensamento pirrônico também não estão em jogo afirmações de cunho dogmático. Diógenes relata que sobre o modo como Pirro se conduzia em sua vida se diziam duas coisas: uma que ele ignorava as leis e os perigos que se punham à sua frente, sendo sempre salvo pelos amigos; outra que ele na verdade viveu longamente e que era um cidadão respeitoso das leis e cuja conduta muitos tinham por exemplo. Montaigne expressamente rejeita a primeira visão. Para ele, Pirro "não quis fazer-se pedra ou cepo" (MONTAIGNE, 2006, p. 259), mas sim um homem que gozasse plenamente de suas faculdades naturais e inclusive de seu corpo. Novamente vemos Montaigne retomar este tema. Parece-nos que usar as partes corporais com "ordem e retidão" envolve, entre outras coisas, a possibilidade de prestar honras a Deus com ele. Na verdade, o que Montaigne quer nos dizer é que Pirro agia como um homem comum, seguindo as aparências, que são o critério da ação cética, sem a elas dar assentimento dogmático e guiando-se pelas quatro regras do ceticismo (inclinações naturais, necessidade das paixões, leis e costumes e a tradição das artes) (SEXTO EMPÍRICO, 2007, p. I20).

Ainda mais, mesmo que o cético deva agir e aja a respeito de algo que ele professa não conhecer, esta não é uma objeção que se possa a ele interpor, pois assim operam os sábios de todas as escolas. Montaigne explica isto com um exemplo clássico: o do barco. Se alguém deve tomar um destes, não pode saber de antemão se chegará ao destino ou se ficará em meio ao caminho, mas ainda assim considera as circunstâncias, a experiência etc. e se decide por tomar o barco ou não, mesmo sem poder dizer conhecer a respeito de seu destino. Neste trecho, Montaigne fala em fazer um juízo de probabilidade acerca destas questões práticas. Sem buscar entrar no mérito, esta questão problematiza seriamente o texto, pois introduz aqui uma temática acadêmica que é rejeitada pelo pirronismo tradicional (MONTAIGNE, 2006 , p. 259). Isto porque, quando se fala em probabilidade ou verossimilhança, supõe-se ao menos a existência de uma verdade à qual algo se assemelha ou aproxima. Contudo, o pirrônico nega a existência de um critério da verdade; o próprio Montaigne o faz expressamente. Diógenes expõe claramente o problema do critério. 
O critério tem ou não tem uma base crítica. Se não tem, carece de credibilidade e não está em condições de apreender nem o verdadeiro nem o falso. Se o critério tem uma base crítica, pertence à classe do juízo particular, de tal maneira que a mesma coisa julga e é julgada, e aquilo que determinou criticamente o critério será criticado por outro critério, e este, por seu turno, por outro, e assim por diante até o infinito (LAÊRTIOS, 20I4, p. 276).

Desta postura do cético que se deixa guiar pelas tradições e aparências, Montaigne conclui que aquele isento dos preconceitos da razão se submete muito mais fácil e docilmente à autoridade política e religiosa, de modo que "tem uma excepcional dianteira rumo à tranquilidade" (MONTAIGNE, 2006, p. 259). Esta facilidade em se deixar conduzir é uma inflexão própria de Montaigne, que o permite operar seu principal distanciamento do pirronismo de Sexto. Para este, a atitude cética permite atingir a tranquilidade a partir do conhecimento da equipolência entre as diversas posições, que faz vã a tomada de posições dogmáticas e a disputa entre doutrinas. Para Montaigne, a doutrina mostra-se útil não apenas por isso, mas a tranquilidade vem na medida em que o ceticismo torna o homem um ser apropriado para receber a iluminação divina e a verdadeira fé, que provém de Deus (MONTAIGNE, 2006). Seu pirronismo se diferencia do tradicional, em primeiro lugar, pois vai ao encontro da fé. Ainda, considerando o contexto dentro do qual a obra foi escrita, essa inflexão religiosa também denota uma política. O homem pirrônico aceita a tradição e a autoridade da religião católica, herdeira legítima de Cristo e seus apóstolos; se fossem todos pirrônicos, não haveriam guerras de religião e o derramamento de sangue que tanto incomodou e chocou o humanista Montaigne.

Vimos mais anteriormente como a razão e a ciência são associadas à soberba. Parece que o propósito argumentativo que guia Montaigne na resposta a esta segunda objeção à obra de Sebond é justamente calcar o orgulho que os homens que julgaram o teólogo catalão têm de seus conhecimentos (MONTAIGNE, 2006). O pirronismo, ao reconhecer a fraqueza natural do homem, retira dele todo o orgulho e o faz aceitar os dogmas estabelecidos pela tradição. Isso se dá pois a esses homens o ceticismo nega os instrumentos pelos quais julgaram os artigos de sua fé, tão piedosamente dispostos e interpretados por Sebond. Decerto que Sexto Empírico não tomou este passo. Para ele, atingida a $\alpha \tau \alpha \varrho \alpha \xi i ́ \alpha$, o pirronismo teria cumprido sua função e o pirrônico continuaria em sua busca pela verdade, a qual a experiência mostra que resultaria pelo menos na grande parte das vezes na descoberta da equipolência e na suspensão do juízo, com a consequente paz de espírito. O cético 
pirrônico é um investigador; a zétesis, da qual tira seu nome, é a disposição de espírito da constante indagação. O cético de Montaigne é o homem piedoso e católico, que, vendo-se impossibilitado de questionar a tradição e a fé, aceita de forma mais mansa e pacífica aquilo sobre o que descobriu que sua razão não pode julgar.

\section{Referências}

BOLZANI, R. Acadêmicos versus Pirrônicos. São Paulo: Alameda, 2013.

FRIEDRICH, H. Montaigne. Berkeley: University of California Press, I99I.

LAÊRTIOS, D. Vidas e doutrinas dos filósofos ilustres. Brasília: UnB, 2014.

MAIA NETO, J. O contexto religioso-político da contraposição entre pirronismo e academia na Apologia de Raymond Sebond. Kriterion, Belo Horizonte, v. 53, n. I26, p. 35I-374, 2012.

MONTAIGNE, M. Os ensaios. Brasília: Hucitec, I987.

Os ensaios, livro 2. São Paulo: Martins Fontes, 2006.

POPKIN, R. The history of scepticism: from Savonarola to Bayle. Oxford: OUP, 2003.

PORGHAT, O. Meu ceticismo. Discurso, São Paulo, v. 46, n. 2, p. 7-36, 2016.

SEXTO EMPÍRICO. Hipotiposes pirrônicas, livro I. In: MARCONDES, D.

(Org.). O que nos fazpensar. Rio de janeiro: PUC-Rio, 2007.

SMITH, P. Sobre a tranquilidade da alma e a moderação das afecções. Kriterion, Belo Horizonte, v. 35, n. 93, p. 22-56, I996.

TOURNON, A. Montaigne. São Paulo: Discurso, 2004.

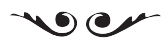

Guilherme Grané Diniz é graduado em Filosofia pela Universidade de São Paulo.

guilherme.diniz@usp.br 